\section{Product and Service Attributes Related to Marketing Nursery Stock}

\author{
Larry D. Makus ${ }^{1}$, \\ John C. Foltz ${ }^{2}$, \\ Joseph F. Guenthner ${ }^{3}$, and \\ Robert R. Tripepi ${ }^{4}$
}

Additional index words. garden center, landscapers, plant wholesalers, landscape plants

Summary. Survey data from 311 garden centers, landscapers, and combined garden center/landscaping firms in selected western United States trade centers were analyzed. Results identified important product and service attributes used in respondent decisions to purchase nursery stock. In general, product characteristics were ranked higher than supplier services. The highest-ranked product characteristics included plants free of insects and disease, properly dug and handled container or balled and burlapped stock, properly dug and handled bare root stock, and plants available when needed. However, several additional product characteristics received high rankings. The highest-ranked service was supplier knowledgeable about plant materials. A $x^{2}$ analysis was conducted to segment this market on the basis of firm size, business type, and geographic location. Results indicated there were limited between-group differences to use in segmenting the market on the basis of size, business type, or location.

University of Idaho, Moscow, ID 8384.3 .

${ }^{\text {I} A s s o c i a t e ~ P r o f e s s o r, ~ D e p t . ~ o f ~ A g r i c u l t u r a l ~ E c o n o m i c s ~}$ and Rural Sociology.

${ }^{2}$ Assistant Professor, Dept. of Agricultural Economics and Rural Sociology.

${ }^{3}$ Associate Professor, Dept. of Agricultural Economics and Rural Sociology.

${ }^{4}$ Associate Professor, Dept. of Plant, Soil, and Entomological Sciences.
$\mathbf{P}$ reduction and marketing of nursery crops has been an increasing component of the agricultural sector in the United States over the past 30 years. Grower cash receipts from greenhouse and nursery crops (the greenhouse and nursery crops commodity group includes turfgrass, bedding plants, cut flowers and greens, foliage and flowering plants, flower and vegetable seeds, bulbs, greenhouse vegetables, and other greenhouse and nursery products) increased from $\$ 661.3$ million in 1960 to $\$ 8.145$ billion in 1990 (Johnson, 1990; Strickland et al., 1991). In real dollar terms, this represents an increase of $181 \%$, for an average annual growth rate of $-6 \%$. In terms ofrelative importance, greenhouse and nursery products represented $1.9 \%$ of total U.S. commodity cash receipts in 1960 and $4.7 \%$ in 1990 (Johnson, 1990; Strickland et al., 1991).

With rapid growth of the market, nursery stock growers need to address the relative importance of product attributes and desired services demanded by their customers. Additionally, understanding buyer behavior is critical in a business with lead times from propagation to market often being long compared with other industries (Phelps, 1984). Knowledge ofservices that plant retailers desire also can be useful to owners and managers of wholesale nursery supply operations.

This paper presents results of a 1990 survey of western garden center and landscaping businesses. The objectives of the research were: 1 ) to assess the relative importance ofselected product and service attributes offered by nursery stock growers and wholesalers (hereafter collectively referred to as plant suppliers), and 2) to determine whether or not the market for nursery stock can be segmented by specific buyer characteristics.

\section{Previous work}

In spite of the growing importance of this commodity group, little empirical work has been done to assess attributes of the market for greenhouse and nursery products. Turner et al. (1990) used telephone survey data to investigate target markets for retail outlets of landscape plants using a tobit model. Results indicated that mass merchandisers and large lawn and garden centers should look at population characteristics of sur- 
rounding neighborhoods when making the decision where to locate.

Prince et al. (1991) investigated retail florists performance ratings of services provided by wholesale growers, wholesale florists, and growershippers/brokers. They applied factor analysis to survey data and identified three major independent classes of service: 1) physical distribution, 2) marketing, and 3) product quality. Florists rated the performance of suppliers physical distribution services higher than marketing services and product quality. Florists perceptions of physical distribution services and product quality were similar for the three supplier groups, but wholesale growers were rated higher in performing marketing services.

Gineo (1989) identified product characteristics that influenced purchase decisions of Connecticut landscapers and retailers when buying nursery stock from wholesalers. Conjoint analysis was combined with a regression model to analyze eight product and service attributes. Results indicated that the dominant characteristic of buyer preference was plant quality. Other factors that significantly influenced buyer behavior were offering a full line of plants, size of plant, origin of the plant, plant price, and the option to pay for purchases with cash. Bryan and Brooker (1989) surveyed 90 nurseries in Tennessee using personal interviews. Although descriptive in nature, their study suggested that further research was needed concerning the marketing infrastructure of the nursery industry.

\section{Methodology}

Data for this study were collected using a mail questionnaire. The survey instrument was pretested using six individuals familiar with the nursery industry in the western United States. After pretesting, the revised questionnaire was distributed to managers of landscape contracting firms and garden centers. Surveys were sent to targeted businesses in Idaho cities with populations $>15,000$ and selected regional trade centers in the western U.S. region, including: Anchorage, Alaska; Denver, Colo.; Billings, Great Falls, and Missoula, Mont.; Reno, Nev.; Salt Lake City, Utah; Spokane, Wash.; and Casper and Cheyenne, Wyo. A total of 549 questionnaires were sent to landscape and garden center businesses identified from state nursery lists and telephone directories. A total of 421 of the identified companies were eligible to participate in the survey. The response rate was $73.9 \%$, with 311 completed surveys returned.

Respondents were asked about their type ofbusiness, seasonality (open seasonally or all year), how long their firm had been in operation, business location, and salesvolume. In addition, firms were asked to indicate the relative importance of 35 attributes associated with the purchase ofnursery stock. These attributes were grouped on the survey into the following areas: a) plant quality, b) plant selection, c) distribution of plants, d) general services, and e) promotional assistance. These five areas were grouped into product characteristics and supplier services for purposes of analysis. Additional questions also were asked to identify the importance of price in respondent purchasing decisions.

The questionnaire used a 4-point scale for ranking the relative importance of the 35 selected attributes in respondents nursery stock purchase decisions. The scale ranged from 1 to 4 , with $1=$ very important, 2 = moderately important, 3 = slightly important, and $4=$ not important. The five questions regarding price were addressed using question-specific response scales.

\section{Results}

Table 1 summarizes selected characteristics of survey respondents. Consistent with the sample, the largest share of respondents was from Idaho $(28.8 \%)$. Other represented states included Colorado, Utah, Washington, Nevada, Alaska, Montana, and Wyoming. Forty percent of the respondents were landscape contractors, but a significant share of the respondents were garden centers or combined landscaper/garden centers. Mass merchandisers or others represented a small share of the total respondents. All sales volume categories were well-represented, with the largest sales category (greater than $\$ 500,000$ ) accounting for the largest share. More than onehalf $(52.1 \%)$ of the firms operated yearround. Almost half $(48.1 \%)$ of the companies had been in business between 6 and 15 years, with the remaining respondents being pretty evenly distributed over the other three

Time in Business categories.

The relative importance of product and service attributes offered by
Table 1. Selected characteristics of surveyed purchasers of nursery stock.

\begin{tabular}{|c|c|}
\hline $\begin{array}{l}\text { Respondent } \\
\text { characteristic }\end{array}$ & $\begin{array}{c}\text { Respondents } \\
(\%)\end{array}$ \\
\hline \multicolumn{2}{|l|}{ Location } \\
\hline Idaho & 28.8 \\
\hline Colorado & 26.9 \\
\hline Utah & 13.3 \\
\hline Washington & 7.1 \\
\hline Neveda & 6.8 \\
\hline Alaska & 5.8 \\
\hline Montana & 5.2 \\
\hline Wyoming & 4.5 \\
\hline Other states & 1.6 \\
\hline \multicolumn{2}{|l|}{ Business type } \\
\hline Landscape contractor & 40.7 \\
\hline $\begin{array}{l}\text { Combined landscaper/garden } \\
\text { center }\end{array}$ & 36.4 \\
\hline Garden center & 21.2 \\
\hline Mass merchandiser or other & 1.7 \\
\hline \multicolumn{2}{|l|}{ Sales volume } \\
\hline Less than $\$ 100,000$ & 17.5 \\
\hline$\$ 100,000-\$ 249,999$ & 29.4 \\
\hline$\$ 250,000-\$ 500,000$ & 21.7 \\
\hline More than $\$ 500,000$ & 31.4 \\
\hline \multicolumn{2}{|l|}{ Period of operation } \\
\hline Year-round & 52.1 \\
\hline Seasonal & 47.9 \\
\hline \multicolumn{2}{|l|}{ Time in business } \\
\hline 5 years of less & 15.3 \\
\hline $6-15$ years & 48.1 \\
\hline $16-30$ years & 17.6 \\
\hline 30 years or more & 19.0 \\
\hline
\end{tabular}

nursery stock suppliers was assessed by comparing the mean responses of the 35 selected attributes (Table 2). Based on the scale used to rank the attribute, a lower mean value implies a higher level ofimportance. In general, almost all of the product attributes were viewed as important, with a mean response between very important and moderately important (ranging between 1 and 2). Product quality, especially with regard to being free of insects and diseases as well as proper handling, appeared to be very important to purchasers of nursery stock. Other important product characteristics included plants available when needed, uniformity with regard to size and quality, and having plants acclimated to the area.

Most of the the supplier services also were identified as important. However, when considered in aggregate, the mean responses for service attributes (Table 2) indicated services were viewed as somewhat less important than product characteristics. Sup- 
Table 3. Relative importance of price to surveyed purchasers of nursery stock. ${ }^{z}$

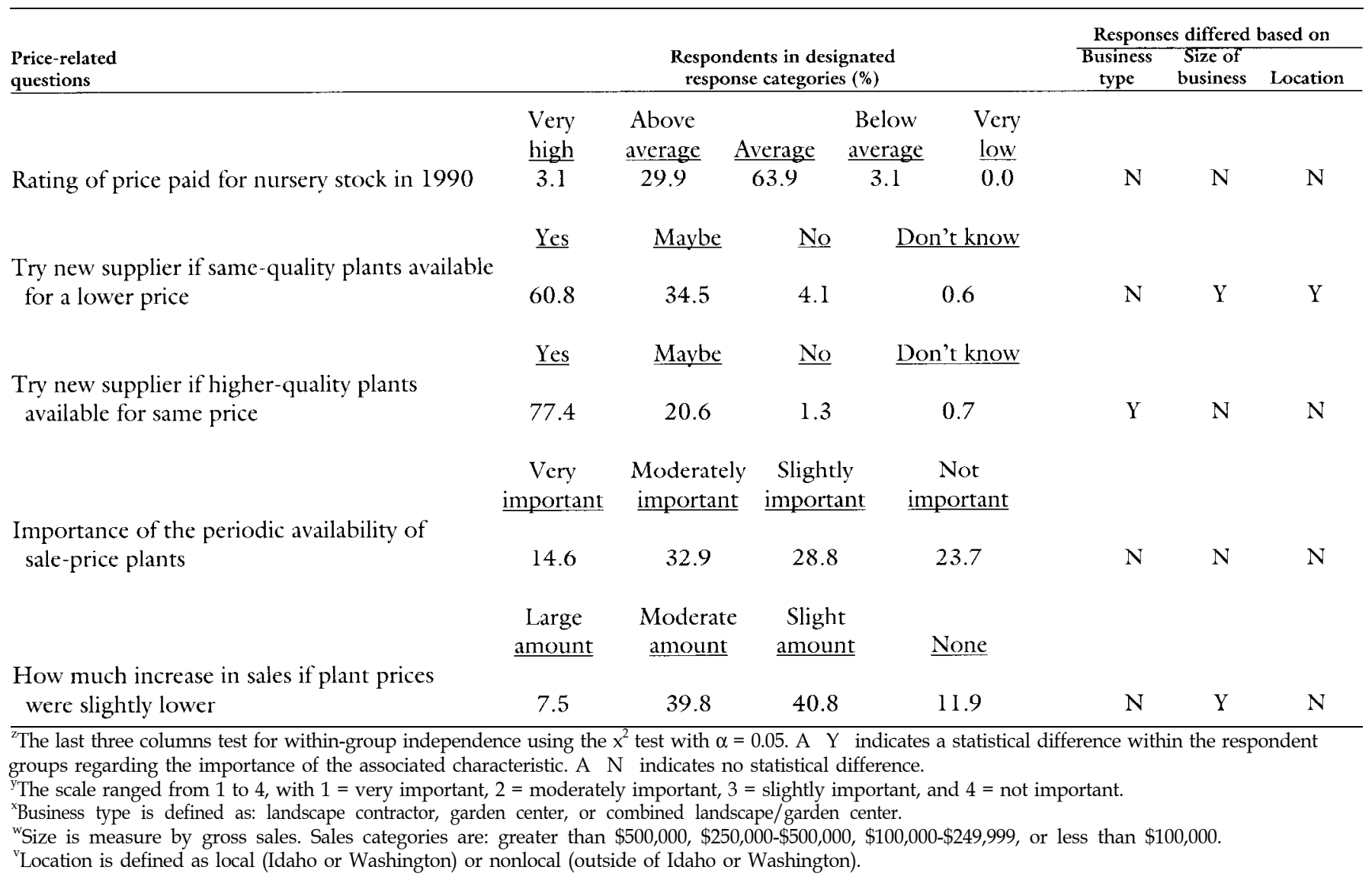

ing the importance of the associated characteristic. A similar analysis was completed for the price-oriented questions (Table 3).

Overall, respondents had similar perceptions about the importance of most product and service attributes. This similarity provided little opportunity to segment the market based on the three selected buyer characteristics. With regard to the selected product and service attributes, only 16 of the 105 tests identified a statistical withingroup difference (grouped by business type, size, or location). With regard to price, only four of the 15 tests indicated a significant difference within the respondent groups.

Plants free of weeds were less important to landscaping businesses compared to garden centers and combined operations. This difference may be due to the fact that landscape contractors select plants for use at a job site, but consumers select their own plants at retail garden centers. Similarly, landscapers and combined landscape/garden center operations indicated that plants available in several sizes was of less importance than did garden centers. Availability of plants in containers instead of balled and burlapped was also relatively less important for landscape firms compared to garden centers. Containerized plants are more convenient for hauling by retail customers, and retail customers generally purchase smaller plants better-suited to containers (Davidson et al., 1988).

Shipping costs were identified as more important by garden centers when compared to landscapers and combined landscaper/garden centers. Of the three business types, garden centers tend to compete relatively more on the basis of providing a product rather than a service. Additionally, garden centers compete for sales of plant materials most directly with mass merchandisers who use price as their primary competitive tool. Service-based firms (such as landscapers) tend to differentiate themselves on the basis of service quality. In contrast, productbased firms often are required to compete more aggressively on the basis of output price (Kotler and Armstrong, 1989). Thus, garden centers are probably more competitive on plant prices than landscapers, and they need to control costs in order to maintain this price competitiveness. Landscapers often are concerned with bidding on jobs where they can differentiate themselves from competitors through services they offer. When a broad range of services is included, the price of plants may not be crucial.

Shipments on time for peak season sales were more important for landscapers and combined landscape/ garden center businesses. This result would appear to be counter-intuitive, since garden centers have more customer contact and would be expected to need plants when consumer demand exists. However, landscape firms need to meet contracts with a time deadline and order plants as needed rather than maintain a large product inventory.

Shared advertising was more important to garden centers than the other business types. This result can be attributed to the need for focused, consumer-based advertising by a garden center. In contrast, the service nature of the landscaper requires less advertising and their advertising tends to have a more general focus. Descriptive tags furnished by the nursery stock supplier were viewed as more critical by garden centers and combined landscape/garden center firms than by 
Table 2. Differentiating nursery stock retailers by perceived need for product characteristics and supplier service offered by nursery stock suppliers. ${ }^{z}$

\begin{tabular}{|c|c|c|c|}
\hline Variable & $\begin{array}{c}\text { Average } \\
\text { response }{ }^{\mathrm{y}}\end{array}$ & $\begin{array}{c}\text { Business } \\
\text { type }^{x}\end{array}$ & $\begin{array}{l}\text { Size of } \\
\text { business }^{\mathrm{w}} \text { Location }\end{array}$ \\
\hline
\end{tabular}

Product characteristics

Plants free of insects or disease

Properly dug/handled container or balled \& burlapped stock

Properly dug \& handled bare-root stock

Plants available when needed

Plants uniform in size \& quality

Availability of plants acclimated to your area

Plants properly pruned or sheared

Root-pruning of large trees before digging

Plants free of weeds

Wide selection of plant species available

Plants available in several sizes

Availability of new plant varieties

Availability of plants in containers instead of

balled \& burlapped plants

Availability of plants in bloom

Other growers located nearby for additional plant selection

Plants available for late-season re-stocking Supplier services

Supplier knowledgeable about plant materials

Plants not damaged during shipping

Shipments on time for peak-season sales

Notification of order shortages before shipping

Furnish catalogs with good plant descriptions

Shipping costs

Time in transit

Supplier willingness to ship small quantities

Scheduled deliveries during the peak season

Regular contact with plant supplier

Previous experience with plant supplier

Furnish tags explaining plant characteristics

Ability to pool shipments with suppliers located

close to each other

Availability of a toll-free telephone number

Furnish plant care instructions

Shared advertising

Furnish promotional items

Availability of a fax number

Major credit cards accepted

$\begin{array}{lll}1.0 & \mathrm{~N} & \mathrm{~N}\end{array}$

$\begin{array}{llll}1.1 & \mathrm{~N} & \mathrm{~N} & \mathrm{~N} \\ 1.2 & \mathrm{~N} & \mathrm{~N} & \mathrm{~N} \\ 1.2 & \mathrm{~N} & \mathrm{~N} & \mathrm{~N} \\ 1.3 & \mathrm{~N} & \mathrm{~N} & \mathrm{~N} \\ 1.3 & \mathrm{~N} & \mathrm{~N} & \mathrm{~N} \\ 1.5 & \mathrm{~N} & \mathrm{Y} & \mathrm{Y} \\ 1.5 & \mathrm{~N} & \mathrm{~N} & \mathrm{~N} \\ 1.6 & \mathrm{Y} & \mathrm{N} & \mathrm{N} \\ 1.6 & \mathrm{~N} & \mathrm{~N} & \mathrm{~N} \\ 1.9 & \mathrm{Y} & \mathrm{N} & \mathrm{N} \\ 2.0 & \mathrm{~N} & \mathrm{~N} & \mathrm{~N}\end{array}$

$\begin{array}{llll}2.1 & \mathrm{Y} & \mathrm{N} & \mathrm{N}\end{array}$

$\begin{array}{llll}2.2 & \mathrm{~N} & \mathrm{~N} & \mathrm{~N}\end{array}$

$\begin{array}{llll}2.2 & \mathrm{~N} & \mathrm{~N} & \mathrm{~N}\end{array}$

$\begin{array}{lll}2.3 & \mathrm{~N} & \mathrm{~N}\end{array}$

$\begin{array}{llll}1.2 & \mathrm{~N} & \mathrm{~N} & \mathrm{~N} \\ 1.4 & \mathrm{~N} & \mathrm{~N} & \mathrm{~N} \\ 1.4 & \mathrm{Y} & \mathrm{N} & \mathrm{N} \\ 1.5 & \mathrm{~N} & \mathrm{~N} & \mathrm{Y} \\ 1.5 & \mathrm{~N} & \mathrm{~N} & \mathrm{~N} \\ 1.6 & \mathrm{Y} & \mathrm{N} & \mathrm{Y} \\ 1.6 & \mathrm{~N} & \mathrm{~N} & \mathrm{~N} \\ 1.7 & \mathrm{~N} & \mathrm{Y} & \mathrm{N} \\ 1.7 & \mathrm{~N} & \mathrm{~N} & \mathrm{~N} \\ 1.7 & \mathrm{~N} & \mathrm{~N} & \mathrm{~N} \\ 1.7 & \mathrm{~N} & \mathrm{~N} & \mathrm{~N} \\ 1.7 & \mathrm{Y} & \mathrm{N} & \mathrm{N}\end{array}$

${ }^{\mathrm{z}}$ The last three columns test for within-goup independence using the $\mathrm{x} 2$ test with $\alpha=0.05$. A $\mathrm{Y}$ indicates a statistical difference within the respondentgroups regarding the importance of the associated characteristic. A $\mathrm{N}$ indicates no statistical difference.

${ }^{\mathrm{y}}$ The scale ranged from 1 to 4 , with 1 = very important, 2 = moderately important, 3 = slightly important, and $4=$ not important.

${ }^{x}$ Business type is defined as: landscape contractor, garden center, or combined landscape/garden center.

${ }^{\mathrm{w}}$ Size is measure by gross sales. Sales categories are: greater than $\$ 500,000, \$ 250,000-\$ 500,000$, $\$ 100,00-\$ 249,999$, or less than $\$ 100,000$.

Location is defined as local (Idaho or Washington) or nonlocal (outside of Idaho or Washington).

plier knowledge of plant materials and the quality and timing of plant shipments were identified as important services. Accepting credit cards, having a fax number, and providing promotional items were identified as lessimportant service features.
The role of price in nursery stock purchases was addressed with a series of five questions (Table 3). Overall, respondents appeared to consider price a secondary criterion in purchasing decisions. Respondents knew the survey was being conducted to provide infor- mation to plant suppliers. Yet, when presented with an opportunity to comment on prices to this group ofpotential suppliers, almost two-thirds of the respondents indicated 1990 prices were about average. Even though $\approx 60 \%$ indicated that they would change suppliers if the same-quality plants could be purchased for a lower price, $77 \%$ indicated that they would change for a higher-quality plant at the same price.

Additionally, the availability of sale-priced plants seemed unimportant in purchasing decisions. The final price question (expected increase in sales due to lower prices) provided a possible explanation. About $81 \%$ of the responding firms indicated that sales would increase only "slightly" to "moderately" if plant prices were slightly lower. Respondents apparently viewed other product or service attributes as being more influential than price when selling plants to their customers. A California survey of lawn and garden center customers provided similar evidence (Stamen et al., 1990).

Selected buyer characteristics were used to determine the potential for segmenting the market serviced by nursery stock suppliers. Market segmentation is defined as the process of classifying customers into groups with different needs, characteristics, or behavior (Kotler and Armstrong, 1989). Market segments consist of customers who respond in similar ways to a given set of marketing stimuli, such as the product mix, promotions and advertising, and pricing. Marketing efforts can be enhanced by targeting one or more market segments and focusing on meeting the distinct needs of the targeted group.

A $x^{2}$ test (Conover, 1980) for within-group independence was used to determine if the relative importance of product and service attributes differed by: a) size of firm based on sales volume, b) type of business, or c) geographic location (Table 2). Since respondents generally rated all of the attributes as very to moderately important, responses were grouped into two categories (very important $=1$ vs. less important $=2,3$, or 4 ) for all of the $x^{2}$ tests. Additionally, because only five respondents were classified as mass merchandisers or "other," their responses were eliminated from the $x^{2}$ analysis. A "Y" indicates a statistical difference (at the 5\% significance level) within the respondent groups regard- 
landscapers. This service is also more important for a retail business that deals directly with individual customers in a store setting. Promotional items offered by plant suppliers were identified as more important to landscapers and combined landscape/garden center firms. However, all firms generally ranked this characteristic as relatively unimportant.

Properly pruned or sheared plants were more important to larger firms (more than \$500,000 in annual sales) than those companies with lower sales. Because evaluating this plant characteristic is somewhat technical, larger firms more likely have the expertise required to judge the quality ofpruning and shearing. Larger firms also have larger quantities of similar plant materials, allowing better evaluation of the quality of pruning and shearing. Plant care instructions also were found to be of less importance to larger firms (over $\$ 500,000$ in sales). Larger firms also placed more importance on the availability of a fax number than did smaller firms. However, availability of a fax number generally was viewed as unimportant by all of the responding firms when compared to other services.

Willingness to ship small quantities was more important for smaller firms (those with annual sales less than $\$ 250,000)$. The sales volume associated with smaller firms would imply they are unable to accommodate large shipments from either a storage, merchandising, or cash-flow standpoint.

Nursery stock suppliers from outside the Idaho/Washington area indicated properly pruned or sheared plants were more important than did firms within the two states. Respondents outside of the Idaho/Washington area also rated shipping costs as more important compared to firms in Idaho and Washington. Since the survey came from the Idaho/Washington region, retailers in surrounding states may have been more sensitive to shipping costs.

Acceptance of major credit cards by plant suppliers appeared to be of minor importance to the majority of responding firms. However, responses to this service varied by location. Respondents outside of the Idaho/ Washington area placed a higher level of importance on this service. This result may reflect the fact that firms farther away may be unknown to the suppliers. Thus, a credit card reduces the risk of nonpayment by the retailer as well as potentially being more convenient for both parties.

The survey analysis also showed that firms outside the Idaho/Washington area regarded notification of order shortages before shipping as more important than firms within the region. As the distance from the supplier to retailer increases, the retailer has a greater need for information on order shortages.

Group differences with respect to the five price questions also were limited (Table 3). Fifteen tests for group independence on responses to price resulted in four with a significant difference. Combined landscape/garden center firms were more inclined to switch suppliers if higher-quality plants could be purchased for the same price. Mid-sized firms ( $\$ 100,000$ to $\$ 249,999$ in annual sales) indicated more of a willingness to switch suppliers based on plant price, and smaller firms (less than \$100,000) thought lower plant prices could increase their sales by a large amount. Firms responding from outside the Idaho/Washington region were more likely to switch suppliers if the same quality plants could be purchased for a lower price.

\section{Summary and conclusions}

The greenhouse and nursery products category is increasing in size and relative importance to the agricultural sector. In spite of this increasing importance, limited work has focused on characteristics of the market for greenhouse and nursery products. Potential for continued growth, renewed interest in alternative crops, and the extensive period of time from propagation to sale (especially for nursery crops) suggests a need to develop information on market characteristics. This analysis used a survey of garden centers and landscaping firms in regional trade centers of selected western states to address the relative importance of several product and service attributes associated with nursery crops. Additional analysis was conducted to identify the potential for segmenting the market based on selected firm characteristics.

Market segmentation based on three selected buyer characteristics (business type, size measured by sales volume, and geographic location) was attempted. Overall, the analysis identified limited differences based on the three characteristics. Market segmentation, at least with regard to business type, size, and location, may be an ineffective marketing strategy for nursery stock suppliers.

Wholesale purchasers of nursery stock appeared to be a discerning group, and generally expected a quality product and a high level of service from their plant suppliers. Product characteristics appeared to be somewhat more important than service, but certain product and service attributes were relatively more important than others. A few service attributes were considered unimportant. However, we were unable to segment the market by size, business type, and location using the survey questions. Despite this result, the study provided useful information about important product and service attributes associated with marketing nursery stock.

\section{Literature Cited}

Bryan, H.D. Jr. and J.R. Brooker. 1989. Tennessee $\mathrm{s}$ ornamental nursery industry: Trade flows and marketing practices, Univ. of Tennessee Agr. Expt. Sta. Res. Rpt. 8910.

Conover, W. J. 1980. Practical nonparametric statistics 2nd ed. Wiley, New York.

Davidson, H.R., R. Mecklenburg, and C. Peterson. 1988. Nursery management, administration, and culture. 2nd ed. Prentice Hall, Englewood Cliffs, N.J.

Gineo, W.M. 1989. The impact of product attributes on nursery stock purchases. Dept. of Agricultural Economics and Rural Sociology, Univ. of Connecticut. AERS Staff Paper 89-1.

Johnson, D.C. 1990. Floriculture and environmental horticulture products: A production and marketing statistical review, 1960-88. Washington, D.C.: USDA/ERS, Stat. Bul. 817.

Kotler, P. and G. Armstrong. 1989. Principles of marketing. 4th ed. Prentice Hall, Englewood Cliffs, N, J.

Phelps, E.D. 1984. Identify customers and their motives to expand retail markets. Amer. Nurseryman 1:75-83.

Prince, T.L., H.K. Tayama, and J.R. Grabner. 1991. Description of florists cognitive structure and perceived performance of supplier services through second-order factor analysis. J. Amer. Soc. Hort. Sci. 116(1):161-165.

Stamen, T., J. Chambers, and J. Mamer. 1990. Marketing study of California lawn and garden consumers. Univ. of California Coop. Ext., Riverside County, Moreno Valley, Calif. 


\section{PRODUCTION AND MARKETING REPORT}

Strickland, R., C. Johnson, and B. Williams. 1991. Ranking of states and commodities by cash receipts, 1990. USDA/ ERS Stat. Bul. 832.

Turner, S.C., J.H. Dorfman, and S.M. Fletcher. 1990. Target markets for retail outlets of landscape plants. Southern J. Agr. Econ. 22(1):177-183.

\section{Acknowledgement}

Research for this article was supported by the Idaho Agricultural Experiment. Station under project 054K215. Funding for the project was provided by grants from the Idaho State Board of Education and the Northwest Area Foundation. Appreciation is expressed to two anonymous journal reviewers. 